\title{
Using Whatsapp Group to Increase Mother's Knowledge on TBC in Sambisari Village, Condong Catur, Depok, Sleman, Yogyakarta
}

\author{
$1^{\text {st }}$ Falasifah Ani Yuniarti \\ Nurse Program \\ Universitas Muhammadivah \\ Yogyakarta \\ Yogyakarta, Indonesia \\ falasifah.ani@umy.ac.id
}

\begin{abstract}
The Covid-19 pandemic period that occurred lately, directly changed the plan for the community service process. Health education which is done by face to face meeting, must be changed to an online meeting. Definitely, for people who have not been familiar yet with the applications used, it becomes a challenge. However, after using it, it becomes easier. This article will illustrate the steps in organizing online health education primarily through the WhatsApp application when the authors conducted it with Family Welfare Program (PKK) members in Sambisari Village Neighborhood 08 RW 60, Joho, Condong Catur, Yogyakarta.
\end{abstract}

Keywords-Women's WhatsApp group, WhatsApp-based learning, online meeting

\section{INTRODUCTION}

The Covid-19 pandemic that occurred in the world forces the academic community to make changes in planning the community service that had been prepared previously. The planned meeting with community members in person should be turned into a virtual meeting.

The applications that are often used include zoom, google meetings, and video calls for face-to-face virtual meeting. However, not all community members choose to meet using the aforementioned applications. They prefer other chat applications such as WhatsApp, telegram, messenger, etc for their virtual meetings.

WhatsApp is one of the most downloaded chat groups by the public $[1,2]$. Almost all android-based mobile phones have this application that is owned by Facebook. More than 2 billion people have downloaded it. With the feature enabling WhatsApp groups to accommodate 256 members, WhatsApp is an option for android phone users to create conversation groups [3]. In addition, using the latest version of WhatsApp2.20.189, WhatsApp can be used to make video calls with other 8 users.

The use of WhatsApp application for communication has both advantages and disadvantages. The advantage of using WhatsApp, when compared to calling-based communication, is increasing the communication. Sending messages via WhatsAppis faster than sending email. Through this way of communication, it will reduce the time to meet.
In addition, in terms of members relationship, WhatsApp allows them to shorten hierarchies, increase the involvement of senior members, encourage younger members to seek help, and increase the effectiveness of perceptions in the group [4].

The drawbacks that occur in the use of WhatsApp group includes frequent interruptions in a conversation. In addition, the smartphone's relatively high price, and more time spent on WhatsApp [4].

The sender's emotions can be expressed through the emoticons provided in WhatsApp. There are emoticons expressing joy, sadness, anger, confusion, and so on. In a study conducted by Waterloo, et al, it was found that the use of emoticons in this application is most suitable when compared to other applications [5].

Indonesia ranks third in the world regarding the number of TB sufferers after China and India. About 250 people die due to tuberculosis everyday [6]. Meanwhile, new cases detected are equivalent to death due to an airplane crash. One of the strategies implemented is to collaborate with community organizations in achieving TBC eradication [7]. In this case, the author collaborates with the Subrecipient of TBC-HIV Care 'Aisyiyah Special Region of Yogyakarta.

\section{A. Regional Overview}

Sambisari Village is a village located in Joho Hamlet, Condong Catur Village, Depok Sub-district, Sleman Regency. Sambisari is bounded in the north by Dusun Joho, in the southern part is by Poh Ruboh Village, in the west is by Dormitory Force 403 and in the east is by Gejayan Village. The number of head of the family is 113 , led by a Neighborhood Head, namely the Head of Neighborhood 08. Meanwhile, the mothers are members of the Family Welfare Program (PKK) of Neighborhood 08 (Head of Neighborhood 08, 2020).

\section{B. PKK of Neighborhood 08 Sambisari Village}

Before the pandemic period, the PKK members consisting of the mothers in Neighborhood 08, Sambisari, Condong Catur, Yogyakarta, held a meeting every month on the 17th. In addition, to facilitate the coordination, they had a PKK Sambisari WhatsApp group. There are 74 PKK 
Sambisari WhatsApp group members, with 7 admins. The seven admins consist of PKK heads and dasawisma (10 houses) heads. Through this forum, the PKK members can coordinate, exchange information, invite meetings, discuss, and offer goods or services.

The author takes this opportunity to conduct health education to group members. The material taken is about the efforts to prevent and control tuberculosis during the pandemic. The material was taken because tuberculosis is one of the biggest causes of death from infectious diseases. Indonesia is in the top three of TB sufferers in the world. In the Special Region of Yogyakarta, Sleman Regency is one of the largest and most of it is in Kapanewonan, Depok(subdistrict). However, the TBC issue seemed to sink with other disease issues. Thus, the authors intend to invite the people to realize the threat of $\mathrm{TB}$ disease that can happen to anyone.

\section{ViRTUAL MEETING ON TBC}

The discussion on the implementation of health education about tuberculosis in the PKK Sambisari WhatsApp groups will be divided into several parts, namely planning, implementation, and evaluation.

\section{A. Planning}

In the planning stage, at first, the author contacted the PKK chairman via WhatsApp messages, about the counseling plan. At that time, the PKK chairman welcomed the plan. Further, the implementation date was discussed which was still tentative. Due to the planning of several agendas, the PKK chairman and the author agreed to meet on Friday, 24 April2020.

After the implementation date was agreed, the authors contacted the resource person, namely Mrs. Rakhmawati, S.Psi. as the program coordinator of TB Care 'Aisyiyah in the Special Region of Yogyakarta. He is willing to be the keynote speaker, and this is in line with the program implemented at TB Care 'Aisyiyah.

The next step is to inform the plan to the PKK members. It was done through the WhatsApp PKK Sambisari groups.

\section{B. Implementation}

One day before the agreed day, the authors reminded the arranged plan to the PKK chairman and the keynote speaker as well as to the members.

At the appointed day, the author asked the admin to invite the keynote speaker to the group. The author acted as a moderator. The moderator started by announcing the presentation rundown and rules during the counseling. The first session was the opening, followed by a remark given by the PKK chairman and an introduction from the author. The next session was material presentation by the keynote speaker. The following session was the question and answer session and was ended with a closing.

On the other hand, the rules applied were the obligation for the participants to listen the presentation in any activity held. While the keynote speaker was presenting, the participants were not allowed to discuss things unrelated with the presentation materials. The participants were allowed to give comments or questions during the materials delivery.

Then, in her speech, the chairman expressed her support for the event held and reminded the members to be aware of TBC dangers. She also emphasized the rules delivered by the author.

The next session was the material presentation delivered by Mrs. Rakhma S.Psi. She described the development of the increasing incidence of TB, the signs and symptoms happen, the treatment, the prevention, and the similarities and differences between TB and Covid 19.

The material was delivered by copying and pasting the material that had been prepared previously. Hence, it did not spend much time to type. However, if there were some new additional information important to be given, both the keynote speaker and the author would immediately type it on the screen. The material was given in approximately one hour followed by a question and answer session.

The participants seemed enthusiastic in following the counseling activities in this group, as evidenced by the number of participants who read the messages conveyed by the keynote speaker and the number of questions asked. There were 2 sessions provided to ask questions having 3 questions in each session. The questions were collected and then answered by the keynote speaker assisted by the author. The frequently-asked questions were related to TB in children or often referred to as lung spots, the differences between TB and other diseases, and the participants' experiences with TB sufferers.

After all the questions were answered, it was continued with the distribution of TB-Covid-19 screening link. The participants were given 5 minutes to fill in the link before the meeting ended. The closing was carried out when it reached 30 minutes from the agreed time. Then, the keynote speaker left the group.

\section{Evaluation}

The implementation of the health education program through the WhatsApp groups of PKK members in Sambisari Village ran smoothly. Although there were some participants who were late and did not follow the event from the start, there were some questions asked after the event was closed. However, the authors appreciated it and answered the questions given. The participants expressed their gratitude for the program, so that they could increase their knowledge and the awareness of TB.

\section{CONCLUSION}

Health education through virtual groups, such as WhatsApp, can be conducted not only during the pandemic but also after it is over since it is advantageous. It allows people to avoid crowds, avoid transmission of the virus, and experience easier way in doing the health education.

Better preparation is needed to provide health education using the application. The materials can be given adjusted to the members' smart phone specifications. Hence, it can be accessed by all members. 
The author hopes that virtual meetings can be held again presenting other materials through conversation groups or other applications that can invite many people.

\section{ACKNOWLEDGMENT}

This paper is presented in the Second International Conference on Health, Schience and Technology held by Universitas Aisyiyah Yogyakartaon 18 July 2020 funded by The Nursing Master Program Universitas Muhammadiyah Yogyakarta. Our gratitude is expressed to PKK Sambisari Village, Joho, Condong Catur Yogyakarta and SR TB Care 'Aisyiyah Special Region of Yogyakarta.

\section{REFERENCES}

[1] Montag, C., Błaszkiewicz, K., Sariyska, R., Lachmann, B., Andone, I., Trendafilov, B., Eibes, M., \& Markowetz, A. Smartphone usage in the 21st century: who is active on WhatsApp? BMC Research Notes, 8(1). https://doi.org/10.1186/s13104-015-1280-z. 2015.
[2] Seufert, M., Hoßfeld, T., Schwind, A., Burger, V., \& Tran-Gia, P. Group-based communication in WhatsApp. 2016 IFIP Networking Conference (IFIP Networking) and Workshops, IFIP Networking, pp. 536-541. https://doi.org/10.1109/IFIPNetworking.2016.7497256. 2016.

[3] WhatsApp Inc. About WhatsApp. (n.d.). Retrieved from https://www.whatsapp.com/about/, July 18, 2020.

[4] Mars, M., \& Escott, R. WhatsApp in clinical practice: A literature review. Studies in Health Technology and Informatics, 231, pp. 8290. https://doi.org/10.3233/978-1-61499-712-2-82. 2016.

[5] Waterloo, S. F., Baumgartner, S. E., Peter, J., \& Valkenburg, P. M. Norms of online expressions of emotion: Comparing Facebook, Twitter, Instagram, and WhatsApp. New Media \& Society, 20(5), pp. 1813-1831. https://doi.org/10.1177/1461444817707349. 2018.

[6] Setiap Hari 250 Orang Meninggal akibat TBC di Indonesia. (n.d.). Retrieved from https://mediaindonesia.com/read/detail/275430-setiaphari-250-orang-meninggal-akibat-tbc-di-indonesia, July 18, 2020.

[7] Pusdatin. Dicari para pemimpin untuk dunia bebas TBC. www.who.int/gho/mortality_burden_disease/cause_death/top $10 / \mathrm{en} /$. 2018 